of workmen, whom the poet greeted in a friendly way. $\mathrm{He}$ then said: "Ah! the glory of the day's work, whether with hand or brain. I have tried.

' To exalt the present and the real, To teach the average man the glory of his daily work or trade." "

In this way of life, that was Osler's, each one, he hoped, might learn to drive the straight furrow and so come to the true measure of a man.

\section{A Solid Monument}

The main theme of this address has been the Oslerian Tradition-that is, the influence that Osler's life and personality may have upon the outlook of succeeding generations of medical men when the man himself is gone. This is impalpable and elusive and therefore impossible to convey except in words. But he also left a more solid monument in the shape of a large library, which passed at his death to McGill University, Montreal. This library was formed over the years with a very definite end in view-that is, to illustrate and record with books and manuscripts the whole history of medical science. It was no haphazard collection formed by the mind of a magpie. Its aim was to direct the student to every aspect of the subject through a balanced selection of material. Osler had, of course, his special obsessions, such as Sir Thomas Browne, but in general his survey was sane and serious. This was demonstrated by the highly organized and original plan of the catalogue carefully laid down for the guidance of the two scholars; his cousin Bill Francis and R. H. Hill of the Bodleian, who were designated to carry it into effect, under the direction, as it turned out, of Lady Osler.

The first section was entitled Bibliotheca Prima, to include the works of primary importance produced by the ancient civilizations of the East and by the greatest of the Greeks and the Arabians; by the middle ages, giving only the name of Roger Bacon; and by the sixteenth to the nineteenth centuries, including a special section on anaesthesia. This is followed by the Bibliotheca Secunda, with the names of lesser lights, though still important; then the Bibliotheca Literaria with Browne and Burton in the forefront, followed by the Bibliothecae Historica, Biographica, and Bibliographica, and ending with Incunabula and manuscripts. The organic whole, entitled Bibliotheca Osleriana, contains nearly eight thousand entries, and provides an extraordinary panorama of medical history in an easily assimilated form, a mirror of the mind that produced it. Osler, with the broad sweep of his multifarious interests and duties, could not provide the detailed scholarship needed for the minutiae of accurate annotation. This was supplied in full measure by the meticulous mind of Bill Francis-so full, indeed, was the measure that the years passed and it was not for a decade after Osler's death that the book was published. Lady Osler, compelled to continue living in "The Open Arms" together with the library for much longer than she liked, used to sigh and ask me in despairing tones would this man ever finish his task? But she realized that the foibles of a perfectionist must be respected and that Sir William would have approved. The catalogue as we have it is a monument to all the great physicians that have ever lived and the printed testimony to the value of the Tradition I have tried to define.

\title{
Distribution of Acute Leukaemia in Time and Space. Studies in New Zealand*
}

\author{
F. W. GUNZ, $†$ M.D., PH.D., F.R.A.C.P., M.R.C.P., M.C.P.A. ; G. F. S. SPEARS, B.A., M.SC., DIP.MATH.STATS.
}

Brit. med. F., 1968, 4, 604-608

\begin{abstract}
Cummary: The distribution of leukaemia in time and space was examined by tracing the date of onset and the place of residence in all cases of childhood leukaemia and of acute leukaemia in adults, totalling 1,003 cases, which occurred in New Zealand during the 12 years from 1953 to 1964.

Significant seasonal variations in the onset were found in adults but not in children. Time-space clustering did not occur in adults, but a significant tendency towards it was found in children aged less than 6 years. Since a similar tendency has previously been found by two other groups of investigators it is suggested that leukaemia in young children may have a different aetiology from that occurring at other ages.
\end{abstract}

\section{Introduction}

In 1963 Heath and Hasterlik described a "cluster" of patients with acute leukaemia in Niles, Illinois. In three years, among a population of about 20,000 , there were eight cases of child-

\footnotetext{
* From the Pathology Department, Christchurch Hospital, Christchurch, and the Department of Preventive and Social Medicine, University of Otago, Dunedin, New Zealand.

† Present address: Kanematsu Memorial Institute, Sydney Hospital,
} Sydney, N.S.W., Australia. hood leukaemia, nearly five times as many as would have been expected on the basis of the incidence in other parts of the same State. This report coincided with a reawakening of interest in the theory that human leukaemia, like that in many strains of laboratory mice, might be caused by viruses, and, although the authors merely suggested a relationship to an infectious process, the Niles cluster has been frequently interpreted as indirect evidence in favour of a viral origin of leukaemia.

More or less well documented instances of leukaemia clusters have since been published from many parts of the world, their individual size ranging from two cases upwards. Their significance has remained problematic, for chance alone must cause occasional aggregations of rare events. "The pertinent question is not whether unlikely events are occurring, but whether they are occurring more frequently than expected" (Ederer et al., 1965). Great difficulty has been experienced in deciding whether the spacing or timing of any observed clusters exceeded the limits of chance probability, and conflicting answers to the problem have been published (Pinkel and Nefzger, 1959; Ederer et al., 1964, 1965 ; Heath et al., 1964 ; Knox, 1964 ; Mustacchi, 1965 ; Dowsett, 1966 ; Lundin et al., 1966 ; Mainwaring, 1966 ; Goldenberg and Zarowski, 1967 ; Till et al., 1967). There is agreement that, even if clustering could be shown to exceed expectation, this fact alone would give no information on the causes of the phenomenon. 
We report here the results of an investigation of the occurrence in time and space of acute leukaemia in the New Zealand population. The aim was to determine whether clustering, if observed, was more common than could be expected. We restricted our inquiries to childhood leukaemia and acute leukaemia in adults because we believed that these were the types most likely to show clustering, and that inclusion of other types with a probably different aetiology might dilute the effect if present. The survey was made New Zealand-wide in order to obtain the largest possible numbers of cases, and also to avoid the risk of bias arising from the selection of any circumscribed areas.

\section{Material and Methods}

In the Cancer Death Lists issued by the New Zealand Department of Health a search was made for deaths of children under 15 certified as due to any form of leukaemia and of adults with either acute leukaemia or leukaemia not otherwise specified. These Lists contain extracts from all death certificates in which any form of cancer, including leukaemia, is mentioned as the primary or an associated cause of death. All deaths occurring in the 12-year period between 1 January 1953 and 31 December 1964 were noted, with a view to establishing the date of onset of the disease and the patients' places of residence, the latter defined as that address at which the patient had last lived for at least three months before the onset of the disease.

Hospital records of all patients who had died in hospital were obtained in order to verify the diagnosis and to note the presumed date of onset, which was defined as the date of the first recognizable symptom pointing to leukaemia. Dates to the nearest month were checked independently by correspondence with the patients' private doctors and surviving relatives, whether or not the patients had died in hospital. In a few cases (less than $2 \%$ ) dates of onset were not obtainable. In these the onset was arbitrarily and uniformly fixed as occurring three months before death.

Acute leukaemia was defined according to accepted cytological and clinical criteria, and those adults whose records did not satisfy these criteria unequivocally were excluded from the survey. All cases of childhood leukaemia were included. No attempt was made to subdivide acute leukaemia into types because no uniform criteria could be established, the diagnoses having been made in a large number of laboratories and the original material being frequently no longer available.

Places of residence were confirmed from hospital and doctors' notes. Where doubt existed about the length of the patient's residence at a given address, local electoral rolls were consulted. All addresses were finally plotted on city maps or, for those not residing in cities, on ordnance survey maps with a scale of $1 \mathrm{in}$. to 4 miles $(2.5 \mathrm{~cm}$. to $6.4 \mathrm{~km}$.). In all cases the positions were noted to the nearest half minute of latitude and longitude. This procedure allowed distances between addresses to be calculated to the nearest statute mile $(1.6 \mathrm{~km}$.).

\section{Statistical Analysis}

The method used to investigate the space-time interaction in the various groups of cases examined was that of Knox (1964). The University of Otago's I.B.M. 360 (Model 30) computer was programmed to compute the interval in time between onsets and the distance between places of residence of all pairs of patients. These were in fact computed only when the time interval was less than 12 months and the distance less than 50 miles $(80.5 \mathrm{~km}$.), but the analyses still required over 10 hours of computing time. As described below the number of "close" pairs was regarded as a Poisson variant for the determination of statistical significance. ${ }^{1}$

The seasonal distributions were tested for departure from that expected on a null hypothesis by chi-squared goodness of fit tests.

\section{Results}

The total number of cases in the survey was 1,003 . This comprised all children with leukaemia, including eight with the chronic granulocytic type, and all adults with acute leukaemia known to have died in New Zealand between 1 January 1953 and 31 December 1964 . It is probable that during this period other cases occurred which for various reasons were either not diagnosed or not certified as having had the disease. Their number is unlikely to have been large, for previous work has shown that the accuracy of diagnosis and certification is high in leukaemia. The inclusion of these "missed" cases in the analysis would probably have had little effect on the general findings. Table I shows the age and sex distribution, which resembled that usually found in acute leukaemia. The sex ratio $(M: F)$ was 1.18 and the modal ages were 2.5 years for children under 15 (male 2.5, female 3.5) and 67.5 years for adults (male 77.5 , female 67.5 ).

TABLE I.-Age and Sex Distribution of 1,000 Cases of Acute Leukaemia*

\begin{tabular}{|c|c|c|c|c|c|c|c|}
\hline \multicolumn{4}{|c|}{ Children } & \multicolumn{4}{|c|}{ Adults } \\
\hline $\begin{array}{l}\text { Age at } \\
\text { Onset }\end{array}$ & $M$ & $\mathbf{F}$ & $\begin{array}{l}\text { Both } \\
\text { Sexes }\end{array}$ & $\begin{array}{l}\text { Age at } \\
\text { Onset }\end{array}$ & $\mathbf{M}$ & F & $\begin{array}{l}\text { Both } \\
\text { Sexes }\end{array}$ \\
\hline $\begin{array}{r}0 \\
1 \\
2 \\
3 \\
4 \\
5 \\
6 \\
7 \\
8 \\
9 \\
10 \\
11 \\
12 \\
13 \\
14\end{array}$ & $\begin{array}{r}11 \\
10 \\
25 \\
15 \\
23 \\
12 \\
15 \\
8 \\
7 \\
6 \\
7 \\
7 \\
6 \\
4 \\
5\end{array}$ & $\begin{array}{r}6 \\
10 \\
9 \\
21 \\
9 \\
9 \\
15 \\
8 \\
11 \\
8 \\
2 \\
7 \\
3 \\
4 \\
5\end{array}$ & $\begin{array}{r}17 \\
20 \\
34 \\
36 \\
32 \\
21 \\
30 \\
16 \\
18 \\
14 \\
9 \\
14 \\
9 \\
8 \\
10\end{array}$ & $\begin{array}{l}15-19 \\
20-24 \\
25-29 \\
30-34 \\
35-39 \\
40-44 \\
45-49 \\
50-54 \\
55-59 \\
60-64 \\
65-69 \\
70-74 \\
75-79 \\
80-84 \\
85-89 \\
90+\end{array}$ & $\begin{array}{l}33 \\
19 \\
15 \\
13 \\
15 \\
18 \\
21 \\
33 \\
23 \\
23 \\
46 \\
49 \\
49 \\
16 \\
6 \\
3\end{array}$ & $\begin{array}{r}21 \\
7 \\
11 \\
12 \\
13 \\
23 \\
26 \\
17 \\
24 \\
34 \\
44 \\
42 \\
36 \\
15 \\
7 \\
1\end{array}$ & $\begin{array}{r}54 \\
26 \\
26 \\
25 \\
28 \\
41 \\
47 \\
50 \\
47 \\
57 \\
90 \\
91 \\
85 \\
31 \\
13 \\
4\end{array}$ \\
\hline Total & 161 & 127 & 288 & Total & 382 & 333 & 715 \\
\hline
\end{tabular}

- Including 8 cases of chronic granulocytic leukaemia in children under 15.

TABLE II.-Seasonal Distribution of Onset in 287 Cases of Childhood Leukaemia and 714 Cases of Adult Acute Leukaemia

\begin{tabular}{|c|c|c|c|c|c|c|c|c|}
\hline \multirow[b]{2}{*}{ Month } & \multicolumn{3}{|c|}{ Under 6 Years } & \multicolumn{3}{|c|}{ 6-14 Years } & \multicolumn{2}{|c|}{ Total } \\
\hline & $\mathbf{M}$ & $\mathbf{F}$ & $\begin{array}{l}\text { Both } \\
\text { Sexes }\end{array}$ & $\mathbf{M}$ & $\mathbf{F}$ & $\begin{array}{l}\text { Both } \\
\text { Sexes }\end{array}$ & $\underset{\text { ren }}{\text { Child- }}$ & Adults \\
\hline $\begin{array}{l}\text { Jan. } \\
\text { Feb. } \\
\text { March } \\
\text { April } \\
\text { May } \\
\text { June } \\
\text { July } \\
\text { Aug. } \\
\text { Sept. } \\
\text { Oct. } \\
\text { Nov. } \\
\text { Dec. }\end{array}$ & $\begin{array}{r}10 \\
10 \\
10 \\
10 \\
9 \\
5 \\
5 \\
9 \\
4 \\
6 \\
9 \\
8\end{array}$ & $\begin{array}{l}9 \\
7 \\
2 \\
2 \\
2 \\
3 \\
8 \\
5 \\
9 \\
7 \\
4 \\
6\end{array}$ & $\begin{array}{r}19 \\
17 \\
12 \\
12 \\
11 \\
8 \\
13 \\
14 \\
13 \\
13 \\
13 \\
14\end{array}$ & $\begin{array}{l}5 \\
5 \\
7 \\
6 \\
5 \\
9 \\
4 \\
3 \\
4 \\
4 \\
6 \\
7\end{array}$ & $\begin{array}{l}6 \\
6 \\
7 \\
6 \\
6 \\
6 \\
3 \\
4 \\
9 \\
5 \\
3 \\
2\end{array}$ & $\begin{array}{r}11 \\
11 \\
14 \\
12 \\
11 \\
15 \\
7 \\
7 \\
13 \\
9 \\
9 \\
9\end{array}$ & $\begin{array}{l}30 \\
28 \\
26 \\
24 \\
22 \\
23 \\
20 \\
21 \\
26 \\
22 \\
22 \\
23\end{array}$ & $\begin{array}{l}71 \\
66 \\
57 \\
71 \\
50 \\
45 \\
45 \\
37 \\
67 \\
58 \\
60 \\
87\end{array}$ \\
\hline Total & 95 & 64 & 159 & 65 & 63 & 128 & 287 & 714 \\
\hline \multicolumn{9}{|c|}{ Significances } \\
\hline $\begin{array}{ll}\mathbf{X}^{2} & \ldots\end{array}$ & $\begin{array}{l}7.189 \\
>0.7\end{array}$ & $\begin{array}{c}15.126 \\
>0.1\end{array}$ & $\begin{array}{c}6.358 \\
>0.8\end{array}$ & $\begin{array}{r}5.378 \\
>0.9\end{array}$ & $\begin{array}{l}8.048 \\
>0.7\end{array}$ & $\begin{array}{l}6.812 \\
>0.8\end{array}$ & $\begin{array}{r}4.14 \\
>0.95\end{array}$ & $\begin{array}{l}36.050 \\
<0.001\end{array}$ \\
\hline
\end{tabular}

\section{Date of Onset}

Table II lists all cases except two, arranged according to the month of onset. Children under 6, all children, and all adults were analysed separately. In children there were relatively fewer cases in the winter months (June to August) than during ${ }^{2}$ Copies of the programme are available to those interested by applica-
tion to G. F. S. Spears. 
the rest of the year, but statistically the distribution did not depart from a random one. In adults the distribution was significantly non-random, with a peak in December (that is, summer) and a low in June-August. Fig. 1 shows the seasonal distribution graphically. There was thus no definite evidence of temporal clustering, as described by Lee (1962) and by Knox (1964) in childhood leukaemia, but in adult cases the phenomenon was prominent.

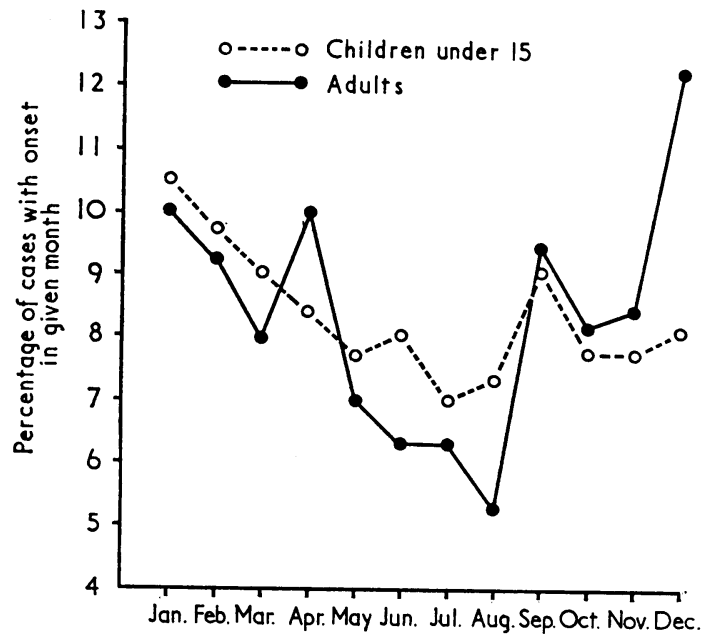

Fig. 1.-Seasonal distribution of onset of leukaemia.

\section{Time-Space Interaction}

Following the method first suggested by Knox (1963), we tested our material to discover whether the time and place of occurrence of cases varied independently. Evidence for an interaction between these two variables would accrue if it were shown that the number of pairs of leukaemia patients residing near each other and with onsets also close together were greater than expected on the assumption of a Poisson distribution of "close" cases. In order to minimize bias we decided, before making the calculations, what would be the critical distances and time intervals to be tested for significance. As we could not fix points of residence more precisely than to the nearest mile $(1.6 \mathrm{~km}$.), this became our minimum distance, while two months was taken as the minimum interval. The four groups defined for analysis were those pairs (a) residing within one mile and with an onset within two months of each other; (b) residing within one mile and with an onset of three months of each other; (c) residing within five miles $(8 \mathrm{~km}$.) and with an onset of three months of each other; (d) residing within 10 miles $(16 \mathrm{~km}$.) and with an onset of six months of each other. We also decided to analyse all cases together, children and adults separately, and, because of Knox's findings, the subgroup of children under 6 years of age.

The results of all calculations are summarized in Table III, and a more detailed sample calculation appears in Table IV. Fig. 2 shows a comparison of the ratios between observed and expected numbers of pairs for children under 6 and for all cases.

Table III discloses no statistically valid evidence of clustering in adults or in all cases. Throughout all cells there is a slight excess of observed over expected cases, but this approaches nowhere near the point of statistical significance. Indeed, many
TABI E IV.-Children Under 6 Years of Age. Time-Distance Distribution of Pairs of Cases

\begin{tabular}{|c|c|c|c|c|}
\hline \multirow[b]{2}{*}{ Distance } & & \multicolumn{2}{|c|}{ Time Interval } & \multirow[b]{2}{*}{ Tota: } \\
\hline & & $\begin{array}{l}\text { Under } 2 \\
\text { Months }\end{array}$ & $\begin{array}{l}2 \text { Months } \\
\text { and Over }\end{array}$ & \\
\hline $\begin{array}{l}\text { Under } 1 \text { mile } \\
1 \text { mile and over }\end{array}$ & \begin{tabular}{l|l} 
\\
$\cdots$
\end{tabular} & $\begin{array}{r}4 \\
272\end{array}$ & $\begin{array}{r}21 \\
12,423\end{array}$ & $\begin{array}{r}25 \\
12,695\end{array}$ \\
\hline Total .. & .. & 276 & 12,444 & 12,720 \\
\hline
\end{tabular}

\begin{tabular}{|c|c|c|c|c|}
\hline \multirow{2}{*}{\multicolumn{2}{|c|}{ Distançe }} & \multicolumn{2}{|c|}{ Time Interval } & \multirow{2}{*}{ Total } \\
\hline & & $\begin{array}{l}\text { Under } \\
3 \text { Months }\end{array}$ & $\begin{array}{l}3 \text { Months } \\
\text { and Over }\end{array}$ & \\
\hline $\begin{array}{l}\text { Under } 1 \text { mile } \\
1 \text { mile and over }\end{array}$ & 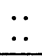 & $\begin{array}{r}4 \\
461 \\
\end{array}$ & $\begin{array}{r}21 \\
12,234\end{array}$ & $\begin{array}{r}25 \\
12,695 \\
\end{array}$ \\
\hline Total ... & . & 465 & 12,255 & 12,720 \\
\hline
\end{tabular}

\begin{tabular}{|c|c|c|c|c|}
\hline \multirow{2}{*}{\multicolumn{2}{|c|}{ Distance }} & \multicolumn{2}{|c|}{ Time Interval } & \multirow{2}{*}{ Total } \\
\hline & & $\begin{array}{l}\text { Under } \\
3 \text { Months }\end{array}$ & $\begin{array}{l}3 \text { Months } \\
\text { and Over }\end{array}$ & \\
\hline $\begin{array}{l}\text { Under } 5 \text { miles .. } \\
5 \text { miles and over }\end{array}$ & $\begin{array}{l}\cdots \\
\cdots \\
\end{array}$ & $\begin{array}{r}9 \\
456\end{array}$ & $\begin{array}{r}208 \\
12,047\end{array}$ & $\begin{array}{r}217 \\
12,503 \\
\end{array}$ \\
\hline Total .. & .. & 465 & 12,255 & 12,720 \\
\hline
\end{tabular}

\begin{tabular}{|c|c|c|c|c|}
\hline \multirow{2}{*}{\multicolumn{2}{|c|}{ Distance }} & \multicolumn{2}{|c|}{ Time Interval } & \multirow{2}{*}{ Total } \\
\hline & & $\begin{array}{l}\text { Under } \\
6 \text { Months }\end{array}$ & $\begin{array}{l}6 \text { Months } \\
\text { and Over }\end{array}$ & \\
\hline $\begin{array}{l}\text { Under } 10 \text { miles } \\
10 \text { miles and over }\end{array}$ & $\because$ & $\begin{array}{r}38 \\
945\end{array}$ & $\begin{array}{r}365 \\
11,372 \\
\end{array}$ & $\begin{array}{r}403 \\
12,317 \\
\end{array}$ \\
\hline Total .. & $\ldots$ & 983 & 11,737 & 12,720 \\
\hline
\end{tabular}

Poisson probability of 38 or more $=0 \cdot 12$.

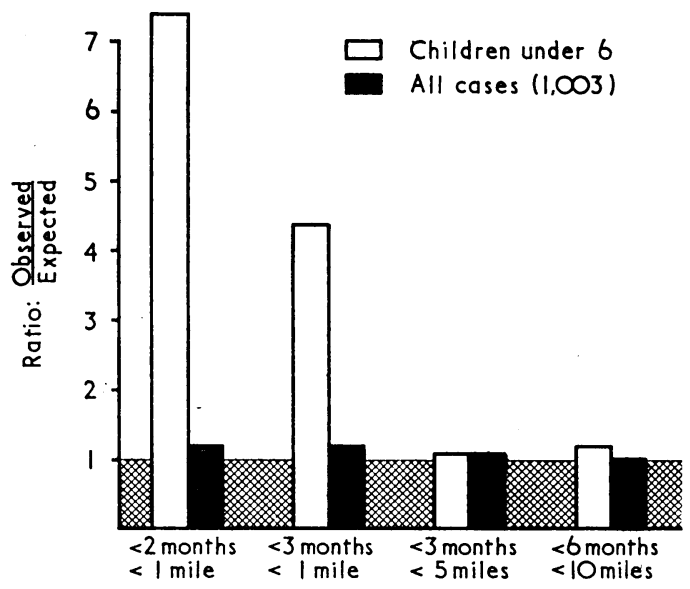

FIG. 2.-Distance apart and comparison of dates of onset of pairs of leukaemia patients. "Expected" numbers of pairs on basis of Poisson distribution of close pairs.

TABLE III.-Observed and Expected Number of. Pairs of Patients at Various Distances and Time Intervals

\begin{tabular}{|c|c|c|c|c|c|c|c|c|c|c|c|c|c|c|c|c|}
\hline \multirow[b]{2}{*}{$\begin{array}{l}\text { Distance and Time } \\
\text { Interval }\end{array}$} & \multicolumn{4}{|c|}{ Children Under 6 Years } & \multicolumn{4}{|c|}{ Children Under 15 Years } & \multicolumn{4}{|c|}{ Adults $15+$} & \multicolumn{4}{|c|}{ All Cases } \\
\hline & Obs. & Exp. & $\begin{array}{l}\text { Ratio } \\
\text { O./E. }\end{array}$ & $\mathbf{P}$ & Obs. & Exp. & $\begin{array}{l}\text { Ratio } \\
\text { O./E. }\end{array}$ & $\mathbf{P}$ & Obs. & Exp. & $\begin{array}{l}\text { Ratio } \\
\text { O./E. }\end{array}$ & $\mathbf{P}$ & Obs. & Exp. & $\left|\begin{array}{l}\text { Ratio } \\
\text { O./E. }\end{array}\right|$ & $P$ \\
\hline $\begin{array}{l}<1 \text { mile }(1.6 \mathrm{~km} .)<2 \text { months } \\
<1 \text { mile }(1.6 \mathrm{~km} .)<3 \text { months } \\
<5 \text { miles }(8 \mathrm{~km} .)<3 \text { months } \\
<10 \text { miles }(16 \mathrm{~km} .)<6 \text { months }\end{array}$ & $\begin{array}{r}4 \\
4 \\
9 \\
38\end{array}$ & $\begin{array}{r}0.54 \\
0.91 \\
7.93 \\
31 \cdot 14\end{array}$ & $\begin{array}{l}7 \cdot 4 \\
4 \cdot 3 \\
1 \cdot 1 \\
1 \cdot 2\end{array}$ & $\begin{array}{l}0.0024 \\
0.013 \\
0 \cdot 39 \\
0 \cdot 12\end{array}$ & $\begin{array}{r}4 \\
5 \\
28 \\
108\end{array}$ & $\begin{array}{r}1 \cdot 389 \\
2 \cdot 399 \\
24 \cdot 030 \\
98 \cdot 042\end{array}$ & $\begin{array}{l}2 \cdot 9 \\
2 \cdot 1 \\
1 \cdot 2 \\
1 \cdot 1\end{array}$ & $\begin{array}{l}0 \cdot 054 \\
0.096 \\
0 \cdot 23 \\
0 \cdot 17\end{array}$ & $\begin{array}{r}25 \\
44 \\
372 \\
1,289\end{array}$ & $\begin{array}{r}21 \cdot 02 \\
35 \cdot 20 \\
343 \cdot 6 \\
1,241 \cdot 8\end{array}$ & $\begin{array}{l}1 \cdot 2 \\
1 \cdot 2 \\
1 \cdot 1 \\
1 \cdot 0\end{array}$ & $\begin{array}{l}0 \cdot 22 \\
0 \cdot 08 \\
0 \cdot 12 \\
0 \cdot 16\end{array}$ & $\begin{array}{r}42 \\
68 \\
589 \\
2,085\end{array}$ & $\begin{array}{r}34 \cdot 2 \\
56 \cdot 8 \\
555 \cdot 4 \\
2,044 \cdot 4\end{array}$ & $\begin{array}{l}1 \cdot 2 \\
1 \cdot 2 \\
1 \cdot 1 \\
1 \cdot 0\end{array}$ & $\begin{array}{l}0 \cdot 11 \\
0 \cdot 08 \\
0 \cdot 15 \\
0 \cdot 30\end{array}$ \\
\hline
\end{tabular}


of the "observed" figures are so close to those " expected" that this finding appears to provide evidence to show that the Poisson model is appropriate for the representation of the distribution of "close" pairs of cases of acute leukaemia.

In the group of all children under 15 the excess of pairs closest to each other in time and space approaches statistical significance. The excess disappears as distances are increased. Further analysis shows that the effect is entirely due to children under 6 , and here the excess of very close pairs, though numerically small, is statistically highly significant. Of the eight children in these pairs, seven were under 4 years of age (three aged 1 , one aged 2 , three aged 3 ) and one was aged 4 . The onset in the members of three of the pairs was within one month of each other.

\section{Discussion}

Clustering of leukaemia cases has been studied since the publication of Heath and Hasterlik's paper in 1963. An earlier report by Kellett (1937) had gone almost unnoticed. Many clusters have been described in the past five years, and in New Zealand, too, apparently unusual aggregations of cases were found when looked for (Gunz, 1966). However arresting such anecdotes might appear, the question could always be asked if they implied significant departures from a chance distribution. To this question no ready answer could be forthcoming because the precise distribution of sporadic leukaemia was not known. Given a sufficiently large area and time span, do cases of the disease occur randomly in space and time, or do those near each other also occur in rapid succession? How usual is it in fact for the lightning to strike twice or more often ? We set out to answer this question for New Zealand.

Several techniques were developed to investigate the problem, and the results, at least in part, depended on the technique used and the material selected. Thus Ederer et al. (1964, 1965) discovered no evidence of clustering among the cases of all types of leukaemia collected by the Connecticut Tumor Registry; the method used was capable of discovering strong clustering in the incidence of poliomyelitis and hepatitis, but possibly it was too insensitive to discover minor aggregations in space and time; perhaps also a different answer might have been obtained if chronic leukaemias had been excluded. Pinkel and Nefzger (1959) described probable clustering in childhood leukaemia in Buffalo, New York, and Mustacchi (1965) in all types of leukaemia in San Francisco. The former findings have been criticized on statistical grounds (Ederer et al., 1964). Knox (1964) showed clustering in children under 6 living in Northumberland and Durham, but when Barton et al. (1965) retested Knox's data by a different method they found no space-time interaction. Finally, weak evidence of clustering in London children under 6 was found by Till et al. (1967) with the use of Knox's method but not with that of Barton et al. (1965).

Our own results show that, in general, acute leukaemia as seen in New Zealand over a period of 12 years did not tend to occur in clusters. On the contrary, the analysis of the pairs of patients showed that those satisfying the criteria of "close" followed the Poisson distribution with surprising faithfulness. However, a small subgroup showed a significant departure from the Poisson model. This consisted of children aged less than 6 years, four pairs among whom developed leukaemia within two months of each other (three within one month) while living within distances of less than one mile $(1.6 \mathrm{~km}$.). Given a random (Poisson) distribution, only 0.54 pairs would have been expected at this distance and time interval. This finding is similar to that of Knox, who discovered five pairs (expected 0.79 ) aged less than 6 years, living within a distance of one kilometre and with onsets within 60 days; and also to that in the recent report of Till et al. (1967), among whose patients under 6 were six pairs (expected 2.67) within similar critical limits $(0.75 \mathrm{~km}$. and 75 days). It was also striking that nearly all the children in the three "positive" groups were very young (Knox: 10/10 children under 4 ; Till et al.: 10/12 children under 4 ; present report: $7 / 8$ children under 4 ). Knox's patients and those of Till et al. were regarded as having lymphoblastic leukaemia, with one exception; no information on the type is available in our cases, but present thinking would assign the great majority of leukaemias in young children to the lymphoblastic type.

\section{Suggested Aetiological Factors}

The three investigations of Knox, Till et al., and our own produced similar findings-namely, an apparently random distribution among the leukaemic population at large but some clustering in the youngest age groups-children under 6 years of age. These studies were carried out with the same statistical method but on dissimilar groups of patients (children in Northern England, both urban and rural, children in London, and children and adults in all parts of New Zealand). The strikingly similar findings suggest that a real difference may exist between the youngest childhood group and all other patients with leukaemia. To account for the clustering it is reasonable to assume the presence, in the youngest group, of aetiological factors which are absent or modified at later ages.

We have no evidence regarding the nature of such factors. Small aggregations of cases may be caused by any number of agencies ranging, in the words of MacMahon (1968), "from genes to lightning bolts." It is interesting, for instance, that the largest "cluster" ever discovered in New Zealand occurred in a single family in which four, and probably five, siblings had acute leukaemia (Gunz et al.; 1966). Genes were here certainly hign on the list of suspected leukaemogens. Most studies in this field have, however, started from the premise that the discovery of significant clustering might provide support for the theory that leukaemia has an infective-possibly viral-origin. The small size of the clusters discovered (including our own) and the absence of known contacts between their members are points against case-to-case infection. The alternative would be "infection" from a common source. Knox found seasonal clustering with a summer peak in his cases, and therefore postulated "a seasonally distributed and clustered event of short duration, that is a trigger mechanism" acting on a widely prevalent underlying factor (? virus) as a possible mechanism. In our own material no seasonal clustering occurred in the only group which showed a significant time-space interactionnamely, young children-and the "trigger" theory thus seems unlikely to be correct. (We have no explanation at present for the marked summer peak in adults-who of course showed no time-space clustering-other than Lee and Gardner's (1965) demonstration that many malignant neoplasms have such a summer peak.)

\section{Latent Period}

In cases of leukaemia where a causative event, such as exposure to ionizing radiations, can be defined the latent period has been found to be of considerable length-that is, 18 months or more (Dameshek and Gunz, 1964). Although in young children it could conceivably be somewhat shorter, the studies of Stewart and Hewitt (1965) make this seem unlikely. But if several years have to elapse after the initiating event it is difficult to see why the onset of leukaemia should be found to cluster. Till et al. thought it more reasonable to expect birth dates to cluster, and in their investigation of leukaemic children they found some evidence pointing to time-space clustering at or about birth. However, Stark and Mantel (1967), with the use of a different statistical technique, obtained negative results when they examined the possibility of space-time clustering of birth dates of Michigan children with leukaemia. 
In spite of the present difficulty of explaining the reason for the clustering in young children with leukaemia, it would seem important to pursue studies in this field. This should be done prospectively in order to make possible an immediate search for aetiological factors as soon as clusters are suspected. The organization of large-scale prospective surveys is beset by many difficulties, but these diminish when it is possible to confine the investigation to well-defined groups. In view of the findings here discussed, it is now suggested that future surveys of leukaemia clusters might with advantage be confined to the group most likely to show the effect-children under the age of 6 years.

This investigation was supported by the Canterbury and Westland Division of the Cancer Society of New Zealand. The field work was conducted by Mrs. Barbara Stroud, for whose skill and enthusiasm we are most grateful.

\section{REFERENCES}

Barton, D. E., David, F. N., and Merrington, M. (1965). Ann. hum. Genet., 29, 97.

Dameshek, W., and Gunz, F. (1964). Leukemia, 2nd ed. New York.
Dowsett, E. G. (1966). Brit. 7. Cancer, 20, 16.

Ederer, F., Myers, M. H., Eisenberg, H., and Campbell, P. C. (1965). f. nat. Cancer Inst. 35, 625.

Ederer, F., Myers, M. H., and Mantel, N. (1964). Biometrics, 20, 626 Goldenberg, G. J., and Zarowski, V. S. (1967). Cancer (Philad.), 20

2.200.
Gunz, F. W. (1966). N.Z. med. 7., 65, 857.

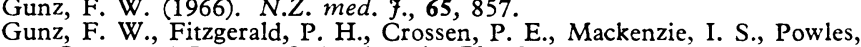
C. P., and Jensen, G. R. (1966). Blood, 27, 482.

Heath, C.' W., jun., and Hasterlik, R. J. (1963). Amer. f. Med., 34, 796.

Heath, C. W., jun., Manning, M. D., and Zelkowitz, L. (1964). Lancet, 2, 136.

Kellett, C. E. (1937). Arch. Dis. Childh., 12, 239.

Knox, G. (1963). Brit. F. prev. soc. Med., 17, $12 \mathrm{i}$

Knox, G. (1964). Brit. F. prev. soc. Med., 18, 17.

Knox, G. (1964). Brit. F. prev. soc. Med., 18,

Lee, J. A. H. (1962). Brit. med. 7., 1, 1737.

e, J. A. H., and Gardner, M. J. (1965). In Current Research in Leukaemia, edited by F. G. J. Hayhoe, p. 266 . London.

Lundin, F. E., jun., Fraumeni, J. F., jun., Lloyd, J. W., and Smith, E. M. (1966). Ұ. nat. Cancer Inst., 37, 123.

MacMahon, B. (1968) Cancer (Philad.), 21, 558.

Mainwaring, D. (1966). Lancet, 2, 393 .

Mustacchi, P. (1965). Cancer (Rhilad.), 18, 362.

Pinkel, D., and Nefzger, D. (1959). Cancer (Philad.), 12, 351.

Stark, C. R., and Mantel, N. (1967). Cancer Res., 27, 1749.

Stewart. A., and Hewitt, D. (1965). In Current Topics in Radiation Research, edited by M. Ebert and A. Howard, p. 221. Amsterdam.

Till, M. M., Hardisty, R. M., Pike, M. C., and Doll, R. (1967). Brit. med. F., 3, 755 .

\title{
Diarrhoea in Kwashiorkor
}

\author{
BRIAN WHARTON,* M.D., M.R.C.P., M.R.C.P.ED., D.C.H.; GLAN HOWELLS, †; IAN PHILLIPS, $\ddagger$ M.A., M.D.
}

\begin{abstract}
Cummary: Diarrhoea was a common problem in the kwashiorkor seen in Kampala, contributing to the mortality and delay in recovery. Enteric infection was found in only a few children $(8 \%)$, but when present it caused particularly severe diarrhoea and was frequently complicated by septicaemia.

Sugar intolerance often occurred to lactose and other sugars, both monosaccharide and disaccharide. The children were most commonly intolerant of lactose, a:d some of these may have had a hereditary lactase deficiency.

Antibiotics are rarely indicated for the treatment of diarrhoea in kwashiorkor in Kampala. If reducing substances are found in the stool of a child on a milk diet, a diet based on sucrose is substituted, and if intolerance persists a fructose diet is given. A few children are intolerant of all sugars, including fructose, and for these the prognosis is grave.
\end{abstract}

\section{Introduction}

In 1908 a curious disease known as "culebrilla" was described in Yucatan, Mexico (Correa, 1908). In this disease, which later became known as kwashiorkor, intractable diarrhoea was the chief sign, and it has remained a prominent feature of all subsequent descriptions. In early work from Uganda, Dean (1952) implicated carbohydrate intolerance, particularly of lactose, as a major factor in the aetiology of the diarrhoea, and

* Paediatrician, M.R.C. Infantile Malnutrition Research Unit, Kampala, Uganda. Present address: Department of Child Health, University of Bristol.

† Technical Officer, M.R.C. Infantile Malnutrition Research Unit, Kampala, Uganda. Present address : M.R.C. Radiobiology Research Unit, Harwell, Berkshire.

¥Lecturer, Department of Microbiology, Makerere Medical School, Kampala, Uganda. lactose intolerance in children with kwashiorkor has been clearly established in Cape Town (Bowie, Brinkman, and Hansen, 1965 ; Bowie, Barbezat, and Hansen, 1967). In other South African centres infection has been thought to be the cause (Kahn, 1959 ; Scragg and Rubidge, 1960), and in Mexico enteritic infection certainly contributes to the high mortality rate (Galván and Calderon, 1965).

The clinical problem in Uganda has sometimes been diarrhoea that appears after a day or so of treatment and becomes increasingly severe. This diarrhoea rarely responded to antibiotics. A lactose-free diet containing glucose and sucrose was not always successful, and one child had reducing substances in his stool when receiving oral dextrose only. The differing views on aetiology and the difficulties of management suggested that a combined clinical, biochemical, and bacteriological approach to the problem might be of value, and this was made in 71 children admitted to the unit for the treatment of malnutrition. Preliminary results were presented at the Cambridge Symposium in 1967 (Wharton, 1968).

\section{Methods}

\section{Bacteriology}

The stools of all the children were examined for the presence of salmonellae, shigellae, and pathogenic Escherichia coli, on admission and thereafter as indicated clinically by persistent diarrhoea or a suspected septicaemia. The samples were cultured on MacConkey agar, desoxycholate-citrate agar, and in selenite broth. Standard bacteriological examinations were also made on specimens from other infected sites. All children with kwashiorkor have diarrhoea. It was regarded as "mild" if the child passed fewer than three stools per day, "moderate" if three to five loose stools were obtained, and "severe" if more than five loose or fluid stools were passed. 